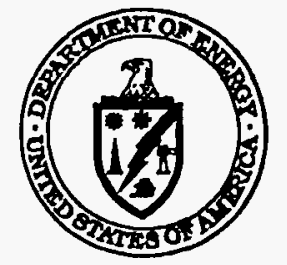

\title{
RCRA Ground Water Assessment Plans and Annual Ground Water Quality Assessment Reports at Interim Status Facilities
}

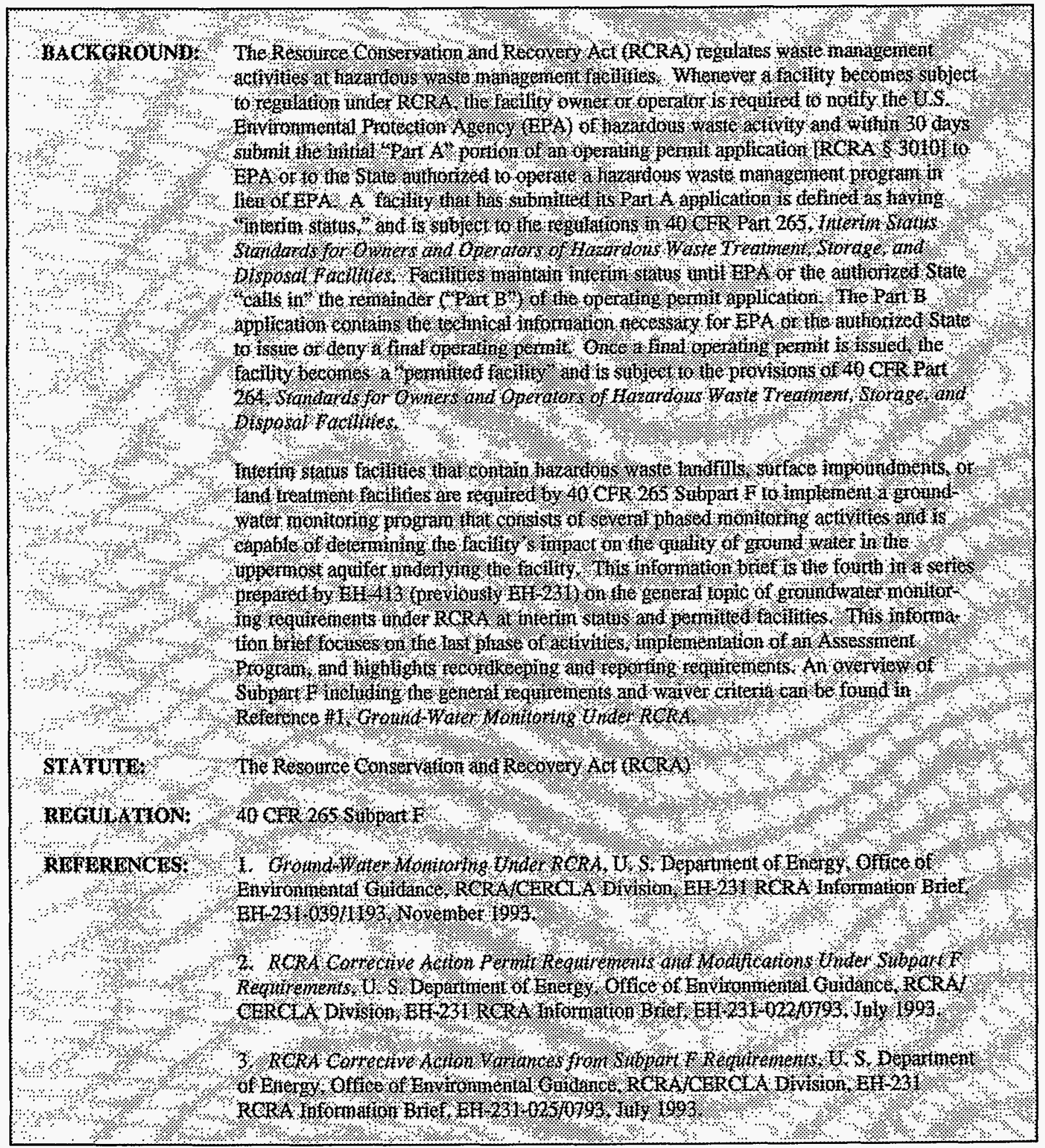


What are the requirements under 40 CFR Part 265 Subpart $F$ for a groundwater monitoring and assessment program at interim status facilities?

The regulations require that the groundwater monitoring and assessment program be capable of determining any impacts which the facility may have on the underlying ground water in the uppermost aquifer. The groundwater monitoring program is typically divided into four phases: (1) development and installation of a groundwater monitoring system, (2) establishment of background water quality, (3) performance of detection monitoring, and (4) implementation of an assessment program. [40 CFR 265.91 and 265.92, 265.93(a), and 40 CFR 265.93(d)|.

[Note: 40 CFR Part 265.90(c) provides for a waiver on all or part of Subpart $F$ if it can be demonstrated that ground water is not vulnerable to contamination from an interim status facility. In addition, 40 CFR Part 265.93(e) provides for a waiver of Subpart $F$ requirements (I) for surface impoundments nunaging corrosive hazardous wastes only, and (2) if it can be demonstrated that, as a result of neutralization of the wastes, there is no potential

for migration of corrosive hazardous wastes out of the impoundment.]

Phase three consists of two parts: (1) detection monitoring and (2) developing an assessment program outline to facilitate the timely implementation of an assessment monitoring program, if necessary. The first three phases are common to all monitoring programs. Implementation of the fourth phase, the assessment program, is dependent upon the results of the detection monitoring in phase three.
INote: A discussion of the regulatory requirements to develop and inplement a groundwater monitoring program can be found in Reference \#1. This Information Brief also provides references to detailed technical information (e.g., characterization of site hydrology; placement, design and construction of monitoring wells; and preparation of sanipling and analysis plans) and other key technical requirements that must be addressed throughout the four phases of developing and implementing a groundwater monitoring program.l

\section{Which interim status facilities are required to prepare a groundwater assessment program outline, and what must the outline contain?}

Interim status facilities that have a surface impoundment, landfill, or land treatment facility must develop an outline of a groundwater quality assessment program that describes a more comprehensive program than the groundwater monitoring program described in 40 CFR 265.91 and 265.92. The outline must include a description of a program that can determine:

- whether or not hazardous waste or hazardous waste constituents have entered the ground water,

- the rate and extent of migration of any hazardous waste or hazardous constituents in the ground water, and

- the concentrations of hazardous waste or hazardous waste constituents in the ground water. [40 CFR 265.93(a)] 
The facility owner or operator must develop this outline within one year of becoming subject to the groundwater monitoring requirements (see Reference \#1).

\section{What is the initial step that must be performed to determine if the facility will be required to implement a groundwater quality assessment program?}

The first step is for the owner or operator of the facility to perform a statistical analysis of the indicator parameters specified in $40 \mathrm{CFR}$ 265.92(b)(3) (i.e., pH, specific conductance, total organic carbon, and total organic halogens) for each well in the monitoring system. For this analysis, the owner or operator must calculate the arithmetic mean and variance, based on at least four replicate measurements on each sample, for each well monitored in accordance with 40 CFR 265.92(d)(2). The samples used in this analysis must be collected and analyzed for the indicator parameters semiannually. The results of the statistical analysis conducted for each well must be compared with its initial background arithmetic mean. The Student's t-test at the 0.01 level of significance must be used to determine statistically significant increases (or decreases, in the case of $\mathrm{pH}$ ) over initial background. (See 40 CFR 265 Appendix IV for a discussion of statistical methods.) [40 CFR 265.93(3)(b)]

\section{DISCLAIMER}

This report was prepared as an account of work sponsored by an agency of the United States Government. Neither the United States Government nor any agency thereof, nor any of their employees, makes any warranty, express or implied, or assumes any legal liability or responsibility for the accuracy, completeness, or usefulness of any information, apparatus, product, or process disclosed, or represents that its use would not infringe privately owned rights. Reference herein to any specific commercial product, process, or service by trade name, trademark, manufacturer, or otherwise does not necessarily constitute or imply its endorsement, recommendation, or favoring by the United States Government or any agency thereof. The views and opinions of authors expressed herein do not necessarily state or reflect those of the United States Government or any agency thereof.

\section{What steps must be performed if the statistical analyses of the indicator parameters show a significant change?}

If a significant change in the groundwater quality is revealed by the statistical analyses (i.e., a significant increase in the contamination of any parameters, or a decrease in $\mathrm{pH}$ ), the owner or operator must perform the following activities:

- For upgradient wells, the facility owner or operator must annually submit the results of the statistical analyses in accordance with 40 CFR 265.94(a)(2)(ii) |i.e., the owner or operator must identify separately any significant differences from initial background levels found in the upgradient wells, in accordance with 40 CFR 265.93(c)(1)]. During the active life of the facility, the information must be submitted to EPA or the authorized State no later than March 1 of the following year. [40 CFR

265.93(c)(1)|

- For downgradient wells, the owner or operator must immediately obtain additional groundwater samples for those wells in which a significant difference was detected. Samples must be split and then analyzed to determine if the significant difference was due to laboratory error. 140 CFR 265.93(c)(2)| If the significant change is determined not to be due to laboratory error, then within 7 days of receiving results confirming the significant change, the facility owner or operator must provide written notice to EPA or the authorized State that the facility's operations may be affecting groundwater quality. [40 CFR 265.93(d)(1)] 
Further, within 15 days after informing EPA or the authorized State, the facility owner or operator must develop a groundwater quality assessment plan based on the groundwater quality assessment outline as required by $40 \mathrm{CFR}$ 265.93(a). The groundwater quality assessment plan must be certified by a qualified geologist or geotechnical engineer. [40 CFR 265.93 (d)(2)]

\section{If the groundwater monitoring system detects contamination by the facility, what are the next steps?}

If the groundwater monitoring system detects contamination by the facility, the fourth phase of the monitoring program is initiated by establishing the groundwater quality assessment program and putting the groundwater quality assessment plan into practice. The groundwater quality assessment plan must include the following:

- the number, location, and depth of the wells;

- the sampling and analytical methods used for determining the hazardous wastes or hazardous waste constituents at the facility;

- the evaluation procedures, including any use of previously gathered groundwater quality information; and

- a schedule of implementation. [40 CFR 265.93(d)(3)]

The groundwater quality assessment plan must, at a minimum, determine the concentrations and the rate and extent of migration of hazardous waste or hazardous waste constituents in the ground water. [40 CFR 265.93(d)(4)]

\section{When must the groundwater quality assessment program be implemented?}

The facility owner or operator must make the first determination of the amount and rate of groundwater contamination as soon as technically feasible. Within 15 days after that determination, the facility must submit to EPA or the authorized State a written report containing an assessment of the groundwater quality. The report must include the concentrations and the rate and extent of migration of hazardous waste or hazardous waste constituents in the ground water.

[40 CFR 265.93(d)(5)]

\section{What actions must be taken if the result of the first determination is that there is no change in the amount of hazardous waste contamination?}

- If no hazardous waste or hazardous waste constituents from the facility have entered the ground water, the facility owner or operator may reinstate the indicator evaluation program described in 40 CFR 265.92 (i.e., phase three of the ground water monitoring program). If the facility owner or operator reinstates the indicator evaluation program, EPA or the authorized State must be notified. [40 CFR 265.93(d)(6)]

- If the results of the sampling do not indicate any significant change in the groundwater quality, the facility owner or operator must, on an annual basis, evaluate the data on groundwater surface elevations obtained under $40 \mathrm{CFR}$ 265.92(e) to determine whether or not the requirements of $40 \mathrm{CFR}$ 265.91(a) for locating the monitoring wells continue to be satisfied. 
- If the evaluation shows that the requirements of 40 CFR 265.91(a) are no longer satisfied, the facility owner or operator must immediately modify the number, location, or depth of the monitoring wells in order to bring the groundwater monitoring system into compliance. [40 CFR 265.93(d)(4)(f)]

\section{What actions must be taken if the result of the first determination is that hazardous waste has entered the ground water?}

If hazardous waste or hazardous waste constituents from the facility have entered the ground water, the required subsequent steps must be based upon whether the groundwater quality assessment plan was implemented prior to final closure of the facility or whether the plan was implemented during the post-closure care period.

- If the facility owner or operator implemented the plan prior to the final closure of the facility, the facility owner or operator must continue making determinations quarterly under 40 CFR 265.94(d)(4) until final closure of the facility. [40 CFR 265.94(d)(7)(I)] Any groundwater quality assessment must be completed and reported in accordance with 40 CFR 265.93(d)(5) (i.e., submit a written report of each determination to EPA or the authorized State within 15 days). [40 CFR 265.93(e)]

- If the groundwater quality assessment program was implemented during the postclosure period, the facility owner or operator may cease determining the rate, concentration, and extent of migration of hazard- ous waste or hazardous waste constituents in the ground water. [40 CFR 265.93(d)(7)(ii)]

\section{What are the recordkeeping and reporting requirements?}

Recordkeeping and reporting is dependent upon whether or not the ground water is monitored as part of the groundwater quality assessment plan required by 40 CFR 265.93 (d)(4). If the ground water is required to be monitored to meet the requirements of a groundwater quality assessment plan, the owner or operator must report and maintain records as follows:

- Report Anmually: Until final closure of the facility, submit a report to EPA or the authorized State that contains the results of the facility's groundwater quality assessment program. The report must include, but is not limited to, the calculated (or measured) rate of migration of hazardous waste or hazardous waste constituents in the ground water during the reporting period. The information must be submitted no later than March 1 of the following year. [40 CFR 265.94(b)(2)]

- Maintain Records: The analyses and evaluations specified in the plan, which satisfy the requirements of $40 \mathrm{CFR}$ 265.93(d)(3), must be maintained throughout the active life of the facility and, for disposal facilities, throughout the period of post-closure care as well. [ $40 \mathrm{CFR}$ 265.94(b)(1)] 
If groundwater monitoring is not required to meet the requirements of a groundwater quality assessment plan as described in $40 \mathrm{CFR}$
- Report concentrations or values of the parameters in 265.92(b)(3) (i.e., $\mathrm{pH}$, specific conductance, Total Organic
UNITED STATES DEPARTMENT OF ENERGY

EH-413

WASHINGTON, DC 20585

OFFICIAL BUSINESS
FIRST-CLASS MAIL

U.S. POSTAGE

PAID

MERRIFIELD, VA

PERMIT NO. 1635 